\title{
Alvászavarok Parkinson-kórban: megjelenés, kivizsgálás, terápiás lehetőségek
}

\author{
Faludi Béla dr. - Janszky József dr. \\ Komoly Sámuel dr. - Kovács Norbert dr.
}

Pécsi Tudományegyetem, Általános Orvostudományi Kar, Klinikai Központ, Neurológiai Klinika, Pécs

\begin{abstract}
Bevezetés: A neurológiai betegségek egyik legnagyobb csoportját a különféle eredetű mozgászavarok alkotják. Ezek közé tartozik a Parkinson-kór, amely a motoros-mozgató rendszert érintő tünetek, panaszok alapján ismerhető fel. A fentiek mellett azonban számos egyéb kísérő jelenséggel is számolni kell, amelyeket úgynevezett nem motoros tüneteknek nevezünk. Ezek közül több meg is előzi az ismert, klasszikus motoros tünetek megjelenését. Célkitüzés: Jelen összefoglaló a Parkinson-kórban megjelenő különböző alvászavarokat, azok felismerési és kezelési lehetőségeit ismerteti. Módszer: A szerzők áttekintették a PubMed-ben található, 2015. januárig megjelent, Parkison-kór és alvászavarok összefüggéseit vizsgáló közleményeket. Eredmények: A nem motoros tünetek egyik kategóriája az alvászavarok, amelyek között megtaláljuk az aluszékonysághoz vezető állapotokat, az insomniát vagy a parasomniák közé soroltREM-magatartászavar-betegséget. Azalvászavarok kialakulásában a neurodegeneratív folyamatkövetkezményeként létrejövő agytörzsi és egyéb területek károsodása mellett (amelyek szerepet játszanak az alvás-ébrenlét ciklus szabályozásában) egyéb, jól befolyásolható faktorok (alvási apnoe betegség, nyugtalan láb szindróma stb.) is szerepet játszanak. Következtetések: A nem motoros panaszok felismerése és megfelelő kezelése a Parkinson-kórban szenvedő betegeknél az életminőséget jelentősen javítja. Orv. Hetil., 2015, 156(27), 1091-1099.
\end{abstract}

Kulcsszavak: Parkinson-kór, alvászavar, REM-magatartászavar, insomnia, alvási apnoe, nyugtalan láb szindróma, terápia

\section{Sleep disturbances in Parkinson's disease: characteristics, evaluation and therapeutic approaches}

Introduction: Parkinson's disease is a well known representant of the movement disorder group of neurological disorders. The diagnosis of Parkinson's disease is based on specific symptoms and signs of movement abnormalities. In addition to classic motor symptoms, Parkinson's disease has characteristic non-motor features, and some of these emerges the classic signs. Aim: The authors discuss characteristics and therapeutic interventions in Parkinson's disease related sleep disturbances. Method: The authors reviewed and summarised literature data on sleep disorders in Parkinson's disease published in the PubMed database up to January 2015. Results: Sleep problems are important non-motor complains (insomnia, hypersomnia, REM behaviour disorder, sleep apnea and restless legs syndrome). The neurodegenerative process of the brain-stem, the effect of symptoms of Parkinson's desease on sleep and concomitant sleep disorders constitute the background of the patient's complains. Conclusions: Appropriate diagnosis and therapy of the consequential or concomitant sleep disorders in Parkinson's disease will help to improve the patient's quality of life.

Keywords: Parkinson's disease, sleep disturbances, REM behaviour disorder, insomnia, sleep apnoe, restless legs syndrome, therapy

Faludi, B., Janszky, J., Komoly, S., Kovács, N. [Sleep disturbances in Parkinson's disease: characteristics, evaluation and therapeutic approaches]. Orv. Hetil., 2015, 156(27), 1091-1099.

(Beérkezett: 2015. április 13.; elfogadva: 2015. május 21.) 


\section{Rövidítések}

MDS-UPDRS $=$ (Movement Disorder Society-Unified Parkinson's Disease Rating Scale) Mozgászavar Társaság-Egységesített Parkinson-kór Pontozó Skála; OSAS = (obstructive sleep apnea syndrome) obstruktív alvási apnoe szindróma; PK $=$ Parkinson-kór; PDSS-2 = (Parkinson's Disease Sleep Scale 2nd version) Parkinson-kór Alvás Skála 2. verzió; PLMD = (periodic limb movement disorder) periodikus végtagmozgászavar betegség; REM = (rapid eye movements) gyors szemmozgások; RLS = (restless legs syndrome $)$ nyugtalan láb szindróma

A neurológiai betegségek egyik legnagyobb csoportja a különféle mozgászavarokkal járó kórképeké. Ezek közül is kiemelt jelentőségú a széles körben ismert Parkinsonkór (PK), amelyet évszázadok óta ismert, tisztán motoros, a betegek mozgásteljesítményét érintő kórképként tartottunk számon. Az utóbbi évtizedekben azonban e téren jelentős változás következett be. Előtérbe került a sokszor klasszikus motoros tüneteket megelőző úgynevezett nem motoros panaszok vizsgálata, így a PK-t kísérő alvászavarok csoportja is [1]. Tekintettel a szemléletbeli és kezelési stratégiákban is bekövetkezett változásra, áttekintjük ezen alvászavaroknak a főbb típusait, vizsgálati és kezelési lehetőségeit.

\section{A Parkinson-kór}

Bár a betegséget világszerte a mai napig James Parkinson nevéhez kötik (mint első leíró), fontos magyar vonatkozása is van. Mintegy 130 évvel James Parkinson előtt egy magyar orvos, Pápai Páriz Ferenc már leírta a jellegzetes tüneteket (tremor, rigiditás, hipokinézia, instabilitás), valamint feltételezte, hogy a panaszok, tünetek agyi károsodás következtében alakulnak ki [2]. Ez a tény, sajnos, nem ment át a köztudatba, feltételezhetóen amiatt, hogy magyar nyelven publikálta felfedezését.

A PK az egyik leggyakoribb neurodegeneratív kórkép. Gyakorisága az 50-60 éves kor közötti populációban $17 / 100000$, idősebbekben pedig 90/100 000, azaz az életkor előrehaladtával egyre gyakoribb. Természetét illetően progresszív lefolyású, az átlagos betegségtartam 15 év. A PK patofiziológiai háttere a substantia nigra neuronjaiban kialakuló eozinofil-synuclein tartalmú zárványok megjelenése.

A kórkép tünete a tremor, amely nyugalmi jellegú, jellegzetes mintázatú, aszimmetrikus kezdetű. Emellett a rigor (testszerte megjelenő izomtónus-fokozódás egyik formája), valamint a mozgások meglassultsága mutatható ki. Jellemző még az apró léptú, csoszogós járás, a karok együttmozgásának elmaradása, a mimikaszegény, kenőcsös arc és a görnyedt testtartás. Tartási instabilitás csak hosszú fennállás után csatlakozik a klinikai képhez.

A klasszikus tünetek mellett számos, úgynevezett nem motoros tünet, panasz is jellemző a PK-ra $[3,4]$. A neuropszichiátriai tünetek között megtalálható például a depresszió és a szorongás, a késői formában a kognitív hanyatlás. A vegetatív idegrendszeri múködészavarokat a hólyagmúködési zavarok, ortosztatikus vérnyomásesés, fokozott verejtékelválasztás adja. A gastrointestinalis rendszert érintő változások következtében például székrekedési hajlam figyelhetô meg. Jellemző továbbá a szaglás zavara, különféle fájdalmak és alvászavarok (1. táblá$z a t)$. A nem motoros tünetek egy része meg is előzheti a klasszikus kép megjelenését.

A neurodegeneratív folyamat nemcsak a substantia nigrát érinti, s nem is ott kezdődik. Braak és mtsai [5] vizsgálatainak alapján a synucleindepozitumok kialakulása az agytörzsben kezdődik, majd rostralisan halad. Megfigyelésük lehetóséget ad a PK-ra jellemző, de nem a klasszikus motoros tünetek közé sorolt jelenségek értelmezésére.

Annak ellenére, hogy a napi gyakorlatban leginkább csak a mozgászavarok tüneteit ismerjük és kezeljük, az egyéb, nem motoros tünetek első leírásai sem mai keletûek, évszázadok óta ismertek [6].

James Parkinsonnak nemcsak a betegség fó jellegzetességeinek a leírását tulajdonítják, hanem ő számolt be elsőként a kísérő székrekedésről, delirosus állapotokról és a fokozott nyálelválasztásról is. A jellegzetes kognitív változások, izomfájdalmak, fáradékonyság leírása Charcot nevéhez füződik. A pszichiátriai vonatkozásokat (depresszió, delusiók) első́ként Gowers rögzítette. A Parkinson-betegséget kísérő fájdalmakra [7] Oppenheim is felfigyelt. Megállapításai szerint ezek a fájdalmak reumatikus jellegúek és megelőzhetik a jellegzetes klinikai kép kialakulását.

1. táblázat |A Parkinson-kór nem motoros tünetei

Tünetek, amelyek megelózhetik a motoros jellegzetességek kialakulását jelentkezését (premotoros fázis)

REM-magatartászavar Szaglászavar

Székrekedés Depresszió

Aluszékonyság

Egyéb nem motoros tünetek, panaszok

Korai fázisban már jelentkező:

\begin{tabular}{ll}
\hline Fáradékonyság & Fájdalmak \\
Insomnia & Súlyvesztés \\
Csökkent szexuális vágy & Hyperhidrosis \\
Gyakori éjszakai vizelés & Homályos látás \\
Ízérzés zavara & Szorongás \\
Impulzuskontroll-betegség & Dopamindiszregulációs \\
Apátia & szindróma \\
\hline
\end{tabular}

Késői fázisban megjelenők:

Major és minor neurokognitív deficit Pszichózis

Hallucinációk

Erectilis diszfunkció

Ortosztatikus vérnyomásesés 
Az alvászavarok és a Parkinson-szindróma összefüggései sem új keletüek. Már James Parkinson klasszikus müvében (Essay on the shaking palsy) is szerepelnek. Megfigyelése szerint az alvás zavart lesz, insomnia alakulhat ki. A betegség terminális szakában a páciens kifejezetten aluszékony, delírium és kimerültség csatlakozik a képhez. Charcot szintén a XIX. században felismerte a rigiditás és bradykinesia alvásra gyakorolt kedvezőtlen hatását.

\section{Alvászavarok Parkinson-kórban}

Az alvászavarok széles skálája megfigyelhető PK-ban (2. táblázat) [1]. Változik a páciens cirkadián ritmusa. Mind insomnia, mind aluszékonyság kialakulásával számolnunk kell. Eredetükként a neurodegeneratív folyamat által érintett, megváltozott agytörzsi szabályozómechanizmusok mellett a betegségre jellemző rigiditás, mozgásszegénység, dystoniák alvást zavaró hatása, valamint jellegzetes organikus alvászavar (alvásfüggő légzés és mozgászavarok) szerepe is felmerül. Külön kiemelendő a REM-magatartászavar jelentősége és a PK-val való asszociációja [8].

A nem motoros panaszok, köztük az alvászavarok keresése, megfelelő kezelése fontos része a PK terápiájának. Az egyes alvászavarok kialakulása, megjelenése korai előrejelzője, preklinikai markere lehet az alapbetegségnek. Ilyen például a REM-magatartászavar-betegség [8]. Más alvászavarok inkább később, a klasszikus motoros szak-

2. táblázat |Az alvászavarok típusai Parkinson-kórban

\begin{tabular}{l}
\hline Elalvási nehezítettségel járó alvászavarok \\
\hline RLS \\
Szorongáshoz társuló alvászavar \\
Cirkadián ciklus megváltozása
\end{tabular}

\begin{tabular}{l}
\hline Átalvási panaszokat okozó alvászavarok \\
\hline Éjszakai hipokinézia/akinézia \\
Izomgörcsök \\
Kora reggeli dystonia \\
PLMD \\
Alvásfüggő légzészavarok (OSAS) \\
REM-magatartászavar \\
\hline Nappali aluszékonyság \\
\hline Alvásrohamok \\
Alvásfragmentációval járó kórképek (PLMD, OSAS) \\
A PK klinikumának éjszakai következményei (izomgörcsök, \\
akinézia, dystonia stb.) \\
Dopaminerg szerek mellékhatása/következménye \\
\hline
\end{tabular}

ban jelentkeznek. Gondoljunk csak az alvás alatti mozgásjelenségekre, dystoniákra stb.!

$\mathrm{Az}$ alvászavarok megjelenése, fennállása tovább rontja a betegek életminőségét. Ez megnyilvánulhat akár a fokozott nappali aluszékonyságban, a gyakori éjszakai ébredésekben, akár az alvásszerkezet elégtelensége miatt kialakuló kognitív változásokban és a nappali fáradékonyságban.

A PK-ban megfigyelhető alvászavarok számos folyamat eredményeként alakulhatnak ki [9]. Eredhetnek a PK-ra specifikus, jellegzetes motoros tünetek, panaszok alvást befolyásoló hatásából. Így például az akinézia, a kora reggeli dystonia, a tremor ébresztő hatása és az átalvási insomnia kialakításában játszott szerepe kétségtelen. Az éjszaka folyamán fiziológiásan is megfigyelhetők mozgások, PK-ban ezek is lecsökkennek, esetleg megszűnnek. A beteg nem tud megfordulni az ágyban, ami diszkomfort érzést vált ki, következményes alvászavarral. Egyes leírások szintén e csoportba sorolják a nyugtalan láb szindrómát és a periodikus végtagmozgászavar betegséget (RLS/PLMD), de ennek hátterében számos más folyamat is állhat. Hatására az elalvási komponens mellett átalvási insomnia kialakulásával is számolnunk kell.

Az alváspanaszok eredhetnek továbbá a PK-hoz köthető, de nem motoros tünetekből. Kialakulásukban a betegséghez köthető hallucinációnak, az időszakos zavart periódusoknak, a jellegzetes fájdalmaknak, izomgörcsöknek, illetve egyes alvásfüggő légzészavaroknak (obstruktív alvási apnoe szindróma - OSAS) lehet szerepe.

A harmadik csoportba többek között a nem csak PKra jellemző, de esetlegesen ráépülő egyéb panaszok (például depresszió) által indukált insomnia (el- és átalvási) vagy a nocturia által indukált átalvási zavar tartozik.

\section{A cirkadián ritmus változása PK-ban}

Jól ismert a PK-ban szenvedő páciensek klinikumának napi fluktuációja, amely érinti a motoros és autonóm funkciókat, az alvás-ébrenlét ciklust, a látást és a dopaminerg terápiára adott választ, hatást is $[10,11]$. A cirkadián mintázat PK-ban az öregedéshez hasonló változásokat mutat (a ciklus úgynevezett amplitúdója beszúkül, csökken a stabilitása, megnövekszik a variabilitása) [12].

PK-ban a motoros funkciók általában rosszabbodást mutatnak a délután folyamán, s a tünetek dopaminerg terápiára adott válasza is lecsökken [10]. A változás a vegetatív funkciókban is kimutatható. Megváltozik a vérnyomás cirkadián mintázata, éjszaka gyakran lehet magas vérnyomásokat mérni, valamint postprandialisan hypotonia észlelhető. Beszúkül a szívfrekvencia cirkadián variabilitása is, a nappali szimpatikus aktivitás csökken.

Ezen ismeretek a PK terápiájában is felhasználhatóak. Adatok bizonyítják, hogy a fényterápia hatással lehet a depresszió mellett a betegségre jellemző bradykinesiára és rigiditásra is [13]. 


\section{Insomnia}

$\mathrm{Az}$ insomnia (amelyet gyakran mint alvásképtelenséget aposztrofálnak) gyakori panasz PK-ban szenvedő betegeknél. Egyes vizsgálatok szerint a páciensek 60\%-a is érintett lehet (míg ez az arány a korban illesztett kontrolloknál csak 33\% volt) [1].

Kialakulásában számos tényező játszhat szerepet. A már fentebb részletezett lehetőségek (PK motoros tünetek következményei, PK nem motoros panaszok következményei és az egyéb ráépülő panaszok, kórképek szerepe) mellett számba kell vennünk többek között a gyógyszeres terápia által indukált változásokat is.

PK-ban a betegek túlnyomó többsége többszöri felébredésről panaszkodik. A felébredések száma 2 és 5 közötti, amelyek hosszabbak, s akár az éjszaka 30-40\%-át is kiteheti az ébren töltött idő [14]. Az insomnia típusai közül az átalvási panaszok (gyakori felébredések) és a korai ébredéssel járó forma a leggyakoribb, a nehezített elalvásra kevesebben panaszkodnak.

Elalvási insomniához (az elalvási idő több mint 30 perc) vezethet a PK-ban gyakoribb RLS, valamint pszichés komponensek. Átalvási insomniához vezethetnek az alvás során jelentkező kóros légzési események, mint például az obstruktív és a centrális apnoe betegség. A felébredések háttérében a PK-t kísérő szenzoros és motoros tünetek, diszkomfort, fájdalom és a bradykinesia, esetleg a periodikus végtagmozgások (PLMD) is állhatnak. A korai ébredés mögött jellegzetes a „kora reggeli dystonia", amely elnyújtott kontrakciókból, dystoniform mozgásokból, a lábak extenziós, flexiós mozgásaiból áll és fájdalom is kíséri. PK-ban változik az éjszakai vizelés is, elnyújtott lesz, akár 20 percig is tarthat, inkomplett, hamarosan ismét jelentkezik, így hozzájárul az alvás folyamatosságának megszünéséhez [15].

Bármilyen folyamat is ébreszti a beteget, az alvás megszûntével számos parkinsonos tünet felerősödik. Ilyen például a tremor vagy a dystoniák, amelyek alvás alatt legtöbbször megszúnnek, felébredést követően pedig ismét megjelennek [1]. Ez viszont megnehezíti a visszaalvást, tovább növelve az ébren töltött időt és csökkentve az alvás hatékonyságát.

$\mathrm{Az}$ említett jelenségek mindegyike emeli a beteg feszültségszintjét, szorongását, s így egyre nehezebben tud visszaaludni. Társulhat insomniához az alvástól való félelem is. Ez már az elalvást is megnehezíti, mivel a beteg tudatában van, hogy mi várható éjszaka, s ezért nem is mer elaludni. A társuló depresszió insomniát kialakító hatását is figyelembe kell venni PK-ban [16].

Amennyiben nem a megfelelő gyógyszeres terápiát, dózisokat választjuk meg a betegünk részére, mi is hozzájárulhatunk az alvászavarához [17]. Ha a dopaminerg medikációt túldozírozzuk, a páciens nehezebben alszik el, hiperaktív lehet éjszaka, hiperszexualitás jelentkezhet, addiktív magatartásformák (például játékszenvedély) alakulhatnak ki. Ez az úgynevezett dopamindiszregulációs szindróma, amely a kezelt PK-s betegek akár 11\%-ában is jelen lehet. Emellett a „túldozírozás” másik jellegzetes hatása lehet a hallucinációk kialakulása.

\section{RLS/PLMD}

A nyugtalan láb szindróma az alsó végtagok kellemetlen dysaesthesiája által indukált akaratlagos mozgástöbbletek, amelyek hatására a panaszok átmenetileg csökkennek. Gyakran társul alvás alatti repetitív, sztereotíp, fázisos lábfej dorzálflexióval, ritkábban a térdízület hajlításával is. Gyakorisága átlag európai populációban 10\% körüli, az életkor előrehaladtával emelkedik.

Míg az RLS-komponens az elalvást nehezíti meg, a PLMD-ben a végtagmegmozdulásokat mikroébredések, ébredések kísérik. Így el- és átalvási insomnia alakulhat ki, következményes másnapi aluszékonyságal.

Az elsődleges formákban - hasonlóan a PK-hoz - dopaminerg hipofunkció mutatható ki. Emiatt felmerült, hogy PK-ban esetleg gyakoribb az RLS/PLMD. A vizsgálatok egyelőre ellentmondóak. Több tanulmány felvetette, hogy PK-ban szenvedő betegek esetén RLS gyakrabban jelentkezik, sőt kialakulása meg is előzi a klasszikus PK-tünetek megjelenését [18]. Más tanulmányok inkább csak „véletlen” egybeesésnek tekintik közös meglétüket. Számos vizsgálat igazolta, hogy a két betegségben észlelt dopaminerg hipofunkciók mögött különböző patomechanizmusok állnak $[19,20]$. A substantia nigra vastartalma PK-ban emelkedett, RLS-ben pedig inkább csökkent. A preszinaptikus dopamintranszportersûrűség RLS-ben normális, PK-ban pedig csökkent. Ezek alapján érthető, hogy nem lehet az RLS-t a PK preklinikai formájának tekinteni.

\section{Aluszékonyság}

A fokozott napközbeni aluszékonyság kifejezetten gyakori panasz PK-ban [1, 21]. A páciensek akár 50\%-a szenved tóle, míg az átlagpopulációban ez az arány csak 11\%. Az aluszékonyság és PK kapcsolatát számos aspektusból vizsgálták. Meglepő adatokat szolgáltatott egy váltott múszakban dolgozók bevonásával készült tanulmány [22]. A váltott múszakos munkarend esetén az alvásidő általában alacsonyabb, ami krónikus alvásmegvonásnak felel meg. A vizsgálat szerint az ilyen munkarendben dolgozók esetén a PK kialakulásának kockázata alacsonyabbnak bizonyult. A hosszabb éjszakai alvásidő viszont korrelált a magasabb PK-kialakulási kockázattal. Hasonló eredményt mutatott a fokozott napközbeni aluszékonyság és PK kapcsolata: az aluszékonyakban nagyobb a PK-kialakulás kockázata. A vizsgálatok konklúziójaként meglepő megállapítást tettek: A váltott múszak (alvásmegvonás) késleltetheti vagy csökkentheti a PK-kialakulási kockázatot, valamint a váltott múszak iránti alacsony tolerabilitás indirekt módon a PK korai markere lehet. 
Egy nagy ázsiai vizsgálat [23] eredménye alapján felmerült, hogy az aluszékonyság megjelenése elöre jelezheti a PK kialakulását, aluszékony felnőttekben a PK kialakulásának kockázata 3,3-szer akkora, mint a nem aluszékonyakban.

Az aluszékonyságot kísérő, speciális figyelmet igénylő jelenség az alvásroham [24]. Jellemzője a minden előjel nélküli hirtelen bealvás, amelyet elsőként Pramipexollal vagy Ropinirollal kezelt PK-pácienseken írtak le. Egy több mint 2000 beteget vizsgáló tanulmány [25] szerint a gyakorisága 6\%, más vizsgálatokban ez az arány elérte a $32-43 \%$-ot is. A hirtelen bealvás, amely a páciensek 1-4\%-ában alakul ki autóvezetés közben, jelentős biztonsági kockázatot képvisel.

Az egyik legfontosabb folyamat, amely az aluszékonysághoz vezet, a PK-ra jellemző neurodegeneratív folyamat. A károsodás érinti az agytörzset, így többek között a locus caeruleust, a reticularis aktiválórendszert. Érintett továbbá a bazális előagyi kolinergiás rendszer és a hypothalamicus orexinrendszer is.

Ezen régiók érintettsége magyarázhatja a fokozott napközbeni aluszékonyságot. Braak és munkatársainak teóriája [5] értelmében az agytörzsi neurodegeneratív folyamat megelőzi a magasabb területek károsodását, így ez magyarázhatja az aluszékonyság korai megjelenését.

A fentiek mellett fontos a gyógyszeres terápiák aluszékonyság kialakulásában játszott szerepe is [24]. A dopaminerg agonisták által okozott aluszékonyság szignifikánsan nagyobb, mint a hagyományos levodopakezelésé. A kettő kombinációja viszont további jelentős kockázatemeléssel jár.

A meglévő primer alvászavarok (például alvási apnoe betegség, nyugtalan láb szindróma, periodikus végtagmozgászavar betegség stb.) repetitív mikroébredéseket okoznak, alvásfragmentációval. Ennek következtében kialakult alvásszerkezeti változásokon, az alvás hatékonyságának csökkenésén keresztül hatnak a napközbeni aluszékonyságra.

Az obstruktív alvási apnoe betegség [26] a garat repetitív elzáródásával, következményes oxigénhiánnyal járó állapot. Az oxigénhiányt és a zárt garat melletti mellkasi erőlködéseket mikroébredések, valódi felébredések kísérik, amelyek megváltoztatják az alvásszerkezetet. Nem tud megfelelően mély alvás kialakulni, ennek következményeként nappal jelentős aluszékonyság jelentkezik.

$\mathrm{Az}$ alvási apnoe betegség különféle formáinak és a PK kapcsolatát, az aluszékonyság kialakulásában játszott szerepét kiterjedten vizsgálják [27]. Jelentőségét az adja, hogy az alvásfüggő repetitív légzészavart kísérő oxidatív stressz, a különféle cardio- és cerebrovascularis betegségek kialakulásában játszott szerepe mellett, fontos tényező lehet a substantia nigrában kimutatható sejtpusztulásban is. Kísérletes adatok is alátámasztják az oxidatív stressznek az alfa-synuclein-aggregációban és dopaminergiás sejtek pusztulásában játszott szerepét [28].
A fenti háttér ismeretében meglepő eredményt hoztak a vizsgálatok [27]. Sem a centrális, sem az obstruktív jellegű légzészavar nem gyakoribb PK-ban, sőt előfordulásuk kevésbé gyakori. Okként felmerült (amit vizsgálatok is alátámasztottak), hogy a PK-ban szenvedő páciensek testtömegindexe alacsonyabb, mint az átlagpopulációé. Egy másik lehetséges ok a PK-ban jellemző REM atónia nélküli jelensége [29]. Normális körülmények között a REM-fázisban fiziológiásan jelen levő atónia megteremti az alapját ebben a fázisban az obstruktív apnoék kialakulásának. Mivel PK-ban a REM atónia nélküli jelensége gyakoribb, így védőfaktor lehet a REM alatti obstruktív események kialakulásában.

$\mathrm{Az}$ alvási apnoe betegség jellegzetes cardiovascularis következményekkel is járhat [30]. Ezek közé tartozik a szívritmuszavarok csoportja. A PK korai nem motoros következményeire jellemző például a szív szimpatikus beidegzésének károsodása [31]. A repetitív apnoék jelentős sympathicotoniával járnak, hozzájárulva a cardiovascularis rizikó növeléséhez. PK esetén viszont a sympathicotonia hatása nem érvényesül a beidegzés károsodása miatt, mintegy védő szerepet szolgáltatva az apnoék egyes következményei ellen [31].

Az alvásfüggő légzészavarok kérdéséhez szorosan kapcsolódik a stridor kérdése. A laringealis funkciók változása, stridor kialakulása gyakori jelenség PK-ban [32]. A stridor magas frekvenciás, belégzésben jelentkező hangfenomén, amely általában alvásban jelentkezik először, s akár életet veszélyeztető állapot is lehet. Következményeként deszaturációk, alvásfragmentáció, ébredések alakulhatnak ki. Poliszomnográfiás vizsgálatok során könynyen összekeverhető egyéb légzészavartípusokkal. PK gyanúja esetén javasolt a stridor kimutatására poligráfiás vagy poliszomnográfiás vizsgálat. Kezelésére sebészeti próbálkozások mellett légsínterápia jön szóba.

\section{REM-magatartászavar}

A REM-magatartászavar-betegséget a parasomniák csoportjába soroljuk. Megkülönböztetünk elsődleges formákat, valamint egyéb betegségekhez kapcsolódó variánsokat. A REM-magatartászavar-betegség gyakran figyelhető meg PK-ban [33].

Alapvető jellemzője az alvás alatti mozgás, amely általában célirányos, különféle cselekvések formájában jelentkezik és megfelel a kísérő álom tartalmának. Gyakran kíséri a saját vagy az alvótárs sérülése, és általában az alvás második felében jelentkezik. A vezető panasz az éjszaka, alvás során jelentkező hatalmas „mozgásvihar”. A mozgások, amelyek során komplex cselekvéssorok (például futásszerú lábmozgások, rúgások stb.) is megjelenhetnek, általában az elalvás után 1,5 órával kezdődhetnek (ez az első REM-fázis kialakulásának az ideje), többnyire azonban a hajnali órákban figyelhetők meg. A betegek egy részénél a tipikus tünetek megjelenése előtt akár évekkel más jellegü alvás alatti motoros események dominálhatnak (például: beszéd alvás alatt, kis izom-össze- 
húzódások). A mozgásviharok gyakorisága alvásonkénti több alkalomtól hetente csak néhány epizódig terjedhet. A betegség idejének fennállásával a mozgásepizódok gyakorisága növekszik.

Előfordulási gyakorisága PK-ban magas, 33-60\%, általában 50-80 éves kor között jelenik meg [33]. A REMmagatartászavar nemcsak a PK jellegzetes mozgási eltéréseinek szakában (úgynevezett nyilvánvaló PK) észlelhető, hanem megelőzi azt, preklinikai markere is lehet a vizsgálatok alapján. Öt éven belül 38\%-ban, 7 év után a REM-magatartásban szenvedő páciensek 65\%ában alakult ki PK.

Létezik a betegség szubklinikus formája, az úgynevezett „REM atónia nélkül” jelensége [34], amely célszerú mozgásokba össze nem rendezett elemi, kis mozgások, izom-összehúzódások meglétét jelenti.

Számos vizsgálat mutatta annak lehetőségét, hogy az idiopathiás forma sok esetben több egyéb, a PK premotoros stádiumára jellemző eltéréssel is társul [35]. Ilyenek például a szaglászavar, kognitív és autonóm érintettség. Ezen eredmények felvetették, hogy a REM-magatartászavar inkább egy komplex neurodegeneratív folyamat része, mintsem egy önálló alvászavar kategória. A korábban elsődleges REM-magatartászavarnak tartott esetek post mortem analízise a minták 97\%-ában kimutatta a neurodegeneratív folyamatot (synucleinopathia) [36].

A REM-magatartászavar megléte PK-ban számos érdekes kérdést vet fel. Ilyen például az, hogy a mozgástöbblet gyors, hirtelen, erôs, simább lefolyású, szimmetrikusabb, amit az alapbetegség nem indokol. Gyakorlatilag a REM-magatartászavar-epizódok alatt eltünik a beteg PK-ra jellemző tünettana [37]. A jelenség patofiziológiai háttere egyelőre nem ismert.

A REM-fázisra jellemző motoros gátlásért a hídban elhelyezkedő subcaeruleusmag múködése felelős. Károsodása a neurodegeneratív folyamat propagációja során (amely a nyúltvelőben kezdődik és halad rostralisan) a synucleinlerakódás következtében alakul ki [35]. Ezek a területek projekciókat küldenek a gerincvelői elülső szarvi motoneuronokra és az agytörzsi mozgató magvakhoz, REM-fázis alatt gátolva azok múködését [38], amellyel kialakítják a fázisra jellemző megszűnő izomtónust. Károsodásuk esetén motoneuronok szabadulnak fel a gátlás alól, így az álomtartalmaknak megfelelő mozgások jelennek meg.

\section{"Sleep benefit"}

A PK-betegek egy részében megfigyelhető az a jelenség, hogy reggel, felébredés után a mozgásteljesítmény viszonylag jó [39]. Jelentkezik ez annak ellenére, hogy a reggeli gyógyszerét még nem vette be. A vizsgálatok szerint ez a betegek 10-20\%-ában figyelhető meg, a tartama 1-1,5 óra. Következményeként akár csökkenthető az első reggeli gyógyszeradag. Kialakulásában szerepet játszat az alvás alatti felhalmozódó dopaminmennyiség.

\section{Kivizsgálási lehetőségek}

Az alvászavarok kivizsgálásának legfontosabb alappillérei a beteg és az alvótárs kikérdezése, a specifikus kérdőívek használata, valamint az előzőekből nyert információk alapján a megfelelő alvásvizsgálat elvégzése.

A páciens és az alvótárs kikérdezésének ki kell terjednie az alvást zavaró, alvás alatt jelentkező mozgásmegnyilvánulás pontos leírására, ismétlődési gyakoriságára, $\mathrm{s}$ annak pontos idózítésére - azaz az alvásidő melyik részében jelentkezik. Fontos annak ismerete, hogy a mozgásmegnyilvánulások járnak-e sérüléssel, illetve összefüggenek-e álomtartalmakkal. Kérdezzünk rá az elalvást megelőző időszak történéseire, zavarja-e valami az elalvást. Horkol-e a páciens, megfigyelnek-e légzéskihagyásokat. Az éjszaki események mellett a kikérdezésnek ki kell terjednie a nappali időszakra is. Kialakul-e aluszékonyság, zavarja-e ez a beteget a mindennapi életvitelben?

A kivizsgálásnak fontos eleme az is, hogy a páciens milyen gyógyszereket szed. Megfelelő-e a páciens antiparkinson gyógyszerelése. Milyen egyéb gyógyszereket szed, amelyek esetlegesen szerepet játszhatnak egyes alvás alatti mozgástöbbletek kialakításában. (Lásd a REMmagatartászavar fejezetet!)

PK esetén több validált, megfelelő szenzitivitással és specificitással rendelkező kérdőív közül választhatunk az alapbetegséghez kapcsolódó alváspanaszok meglétének, típusának és fokának megítélésére. A napi gyakorlatban 2 kérdőív terjedt el, ezek az MDS-UPDRS és a PDSS-2.

Az MDS-UPDRS (Movement Disorder Society-Unified Parkinson's Disease Rating Scale) kérdőív [40] tartalmazza a klasszikus motoros tünetekre vonatkozó kérdések mellett a nem motoros panaszokat érintőket is. Ennek keretében kettő kérdés foglalkozik az alvászavarokkal. Egyrészt rákérdez az alvással kapcsolatos problémákra (tovább nem specifikálva azt), másrészt a napközbeni alváskényszer meglétét és fokát vizsgálja [41, 42].

A kérdőívre adott válaszok alapján kiderülhet alvászavar megléte, amelyet tovább vizsgálhatunk már specifikusan az erre a célra szerkesztett skálákkal. Ilyen például a PDSS-2 (Parkinson's Disease Sleep Scale 2nd version) [43]. Ez a fajta kérdőív rákérdez az összes nagy, PD-ben lehetséges alvászavartípusra és okra [44], valamint alkalmas a terápiás kezelések hatékonyságának mérésére [45].

A nappali aluszékonyság fokának megítélésére az úgynevezett Epworth Álmossági Skála (Epworth Sleepiness Scale - ESS) terjedt el a mindennapi gyakorlatban [46]. A kérdések 8 különféle élethelyzetben meglevő aluszékonyság fokára kérdeznek rá. Ezek felölelik az egyszerü, nem túl nagy figyelmet igénylő helyzetektől (például ebéd utáni éberségi szint) egészen a kifejezett odafigyelést és éberségi szintet kívánó cselekedetekig (például gépjármúvezetés) terjedő skálát.

Amennyiben a panaszok pontos feltérképezésével, az alvótárs kikérdezésével és specifikus kérdőívek alkalmazásával nem tudjuk meghatározni az alvászavar típusát, 
vagy differenciáldiagnosztikai segítségre van szükségünk, alváslaboratóriumi vizsgálatokat végezhetünk. A legteljesebb, szinte mindenfajta alvászavar kivizsgálásában használható eljárás a poliszomnográfia. Videomonitorozással kiegészítve lehetőség van az egyes mozgásjelenségeknek az alvásszerkezettel, alvásfázisokkal, a különféle egyéb, alvás alatti kóros poliszomnográfiás jelenségekkel való összevetésére. A vizsgálat során meghatározhatjuk az alvásszerkezetet, azonosíthatjuk az éber periódusokat, meghatározhatjuk a felébredéshez vezető okokat. Láthatjuk az egyes mozgásjelenségek időzítését, mintázatát, s láthatjuk, hogy mely alvásfázisban jelentkeznek. Meghatározhatjuk a kóros légzési mintázatok típusát (obstruktív, centrális apnoe stb.), gyakoriságát.

A fenti kivizsgálási lehetőségek megteremtik az alapját a hatásos terápiás stratégiák kialakításának.

\section{Terápiás lehetőségek}

\section{Insomnia}

A PK-ban kialakuló insomnia esetén is legfőbb irányelv az oki kezelés, vagyis a háttérben meghúzódó ok (RLS, PLMD, OSAS, REM-magatartászavar, a PK-val járó dystoniák, rigiditás stb.) megfelelő kezelése segítheti elő az alvás javulását. A motoros jelenségek mellett javasolt a nocturia (amely PK-ban dysuria jellegü) keresése és kezelése.

Természetesen javasolt a kísérő depresszió kezelése is [16], azonban ez megfelelő gyógyszerválasztást igényel. A legtöbb antidepresszáns ronthatja a korábban meglévő RLS-t és PLMD-t, valamint szintén rosszabbodhatnak a REM-magatartászavar tünetei is. A vizsgálatok alapján első választandó szerként a bupropion javasolható.

Függetlenül az alapbetegség vagy az alvásfragmentációt előidéző patológiák specifikus kezelésétől, kiegészítésként kognitív magatartás-terápia [47], valamint altatók alkalmazása is javasolt. Sajnos megfelelő tanulmány csak kevés altató, alvást elősegítő hatóanyag esetén áll rendelkezésre PK esetén. Ezek a hatóanyagok például az eszopiclon, a melatonin és a doxepin $[48,49]$.

\section{Fokozott napközbeni aluszékonyság}

Alapvető fontosságú a megfelelő alváshigiénés ajánlások elsajátítása, betartása, a rendszeresség, reguláris alvásébrenlét ciklus kialakítása. Javasolt a nappali szunyókálások kerülése.

Mivel a dopaminagonista gyógyszerek szerepet játszanak az aluszékonyság kialakításában, javasolt a terápia áttekintése. Ez fontos abból a szempontból is, hogy kiderüljön, szed-e egyéb, szedatív, aluszékonyságot okozó gyógyszert a beteg. A lehetőségekhez mérten javasolt mind a dopaminergmedikáció, mind az egyéb szedatívumok dózisának csökkentése.

Tekintettel az aluszékonyság munka- és közlekedésbiztonsági vonatkozásaira [50], fel kell hívni a páciensek figyelmét az ebből eredő veszélyekre. Fokozottan vonatkozik ez azokra a betegekre, akik minden előzetes figyelmeztető jel nélkül hirtelen elalszanak.

Az előzőekben ismertetett lehetőségek, valamint egyes elsődleges alvászavarok (OSAS, RLS) megfelelő terápiája nem minden esetben hozza meg a kívánt hatást. Ilyenkor különféle stimulánsok, éberségi szintet emelő gyógyszerek alkalmazására van lehetőség $[51,52]$, a leginkább elterjedt a methylphenidat (Ritalin). Számos mellékhatása ismert. Ezek a hozzászokási potenciál, cardiovascularis mellékhatások (szívritmuszavar, magas vérnyomás), felhasználhatósága kétséges, nem javasolt.

A jelenlegi leginkább elfogadott gyógyszeres terápia aluszékonyság esetén a Modafinil (Vigil, Modasomil) [51], amely hatását noradrenergiás és dopaminergiás mechanizmusokon keresztül fejti ki. Eredetileg narcolepsia terápiájára alkalmazták.

A stimulánsok alkalmazása nagy körültekintést igényel, különösen a kognitív funkciók csökkenése esetén. Ilyenkor a violens magatartás, zavartság kialakulásának a kockázata nagy.

\section{Nyugtalan láb szindróma, periodikus végtagmozgászavar betegség}

Az RLS és PLMD kezelésében számos gyógyszert használhatunk, ezek egy része a PK terápiájában is használatos.

A legfontosabb alapelv az oki kezelés, amely a másodlagos formák gondos kiderítését követően a háttérben lévő ok kezelését jelenti.

A másodlagos formák közül a legfontosabb és leggyakoribb a vashiány talaján kialakuló mozgástöbblet. Kezelésében a vaspótlás alapvető, akár per os, akár iv., ha nem lenne elégséges a per os bevitel.

A gyógyszeres terápiákban a dopaminergiás agonista gyógyszerek a leghatásosabbak [53]. A napi gyakorlatban a Pramipexolt, a Ropirinolt és a Rotigotint használhatjuk. Mindegyik a PK-ban megszokott dózisoknál kisebb adagban is elégséges. A fentiek mellett gabapentin alkalmazása lehet kedvező a tünetekre, panaszokra [52].

\section{REM-magatartászavar}

A betegség kezelésében elsődleges szerepe a clonazepamnak (Rivotril) van. Már alacsony dózisban is $(0,25-1$ mg) jó hatásfokkal csökkenti a panaszokat. Alkalmazása a hozzászokásveszély és a nappali aluszékonyság kialakulásának lehetősége miatt fokozott elővigyázatosságot igényel. A kezelésben elterjedt még a melatonin alkalmazása [54]. A cirkadián alvászavarok terápiájában használt dózisok sokszorosa adandó, 3-12 mg esténként. Mellékhatások nélkül megfelelő terápiás hatás alakítható ki. Fontos a páciens gyógyszerelésének áttekintése, revíziója. Számos gyógyszer van, amely potencírozza a REMmagatartászavar megjelenését. Ilyenek például a triciklu- 
sos antidepresszánsok és az SSRI-csoportba tartozó antidepresszánsok [14].

A fenti gyógyszeres lehetőségeket ki kell egészíteni a sérülések elkerülése érdekében megtett biztonsági intézkedésekkel. Ennek keretében az alvókörnyezetet biztonságossá kell tenni, a potenciálisan sérüléseket okozó tárgyakat javasolt eltávolítani. Hatásos lehet a nagy mozgások megfékezésére, ha a beteg hálózsákban alszik. Ez korlátozza a mozgásokat, s így védi az alvótársat is.

\section{Következtetések}

A fentiek alapján a PK-ra már nem tekinthetünk úgy, mint egy „egyszerü” mozgásokat érintő betegségre. A kép kitágult, amely ismerete az eredményes kezeléshez, a páciens számára kedvező életminőség kialakításához elengedhetetlen.

Az alvászavarok „társulata” heterogén csoport, különböző patofiziológiai háttérrel és befolyással az alvásminőségre. Megfelelő kivizsgálást követően hatásos terápiák állnak rendelkezésre Parkinson-betegségben szenvedő páciensek esetén is.

A PK nyilvánvaló motoros tünetekkel járó stádiuma előtt számos, már a betegség patofiziológiai sajátságaival összefüggő, nem motoros, premotoros panaszok alakulhatnak ki. Ezek keresése, időben való azonosítása megteremtheti az alapot egyes, jövőbeni korai terápiás beavatkozások alkalmazására.

Anyagi támogatás: A közlemény megírása anyagi támogatásban nem részesült.

Szerzői munkamegosztás: F. B.: A kézirat megszövegezése, diszkusszió. J. J., K. S., K. N.: Diszkusszió. A közlemény végleges változatát valamennyi szerző elolvasta és jóváhagyta.

Érdekeltségek: A szerzőknek nincsenek érdekeltségeik.

\section{Irodalom}

[1] Tandberg, E., Larsen, J. P., Karlsen, K., et al.: A communitybased study of sleep disorders in patients with Parkinson's disease. Mov. Disord., 1998, 13(6), 895-899.

[2] Bereczki, D.: The description of all four cardinal signs of Parkinson's disease in a Hungarian medical text published in 1690. Parkinsonism Relat. Disord., 2010, 16(4), 290-293.

[3] Simuni, T., Sethi, K.: Nonmotor manifestations of Parkinson's disease. Ann. Neurol., 2008, 64(Suppl. 2), S65-S80.

[4] Kincses, P., Kovács, N., Karádi, K., et al.: Critical issues of the biopsychosocial treatment of Parkinson's disease. [A Parkinsonkór biopszichoszociális ellátásának kritikus kérdései.] Orv. Hetil., 2015, 156(12), 472-478. [Hungarian]

[5] Braak, H., Del Tredici, K., Rub, U., et al.: Staging of brain pathology related to sporadic Parkinson's disease. Neurobiol. Aging, 2003, 24(2), 197-211.

[6] Garcia-Ruiz, P. J., Chaudhuri, K. R., Martinez-Martin, P.: Non-motor symptoms of Parkinson's disease A review...from the past. J. Neurol. Sci., 2014, 338(1-2), 30-33.
[7] Aschermann, Z., Nagy, F., Perlaki, G., et al.: 'Wind-up' in Parkinson's disease: A functional magnetic resonance imaging study. Eur. J. Pain, 2015 Mar 12. doi: 10.1002/ejp.659. [Epub ahead of print]

[8] Iranzo, A., Santamaria, J., Rye, D. B., et al.: Characteristics of idiopathic REM sleep behavior disorder and that associated with MSA and PD. Neurology, 2005, 65(2), 247-252.

[9] Maass, A., Reichmann, H.: Sleep and non-motor symptoms in Parkinson's disease. J. Neural Transm., 2013, 120(4), 565-569.

[10] Bonuccelli, U., Del Dotto, P., Lucetti, C., et al.: Diurnal motor variations to repeated doses of levodopa in Parkinson's disease. Clin. Neuropharmacol., 2000, 23(1), 28-33.

[11] Iranzo, A.: Parkinson disease and sleep: sleep-wake changes in the premotor stage of Parkinson disease; impaired olfaction and other prodromal features. Curr. Neurol. Neurosci. Rep., 2013, 13(9), 373.

[12] Van Hilten, J. J., Kabel, J. F., Middelkoop, H. A., et al.: Assessment of response fluctuations in Parkinson's disease by ambulatory wrist activity monitoring. Acta Neurol. Scand., 1993, 87(3), 171-177.

[13] Harrell, L. E., Balagura, S.: The effects of dark and light on the functional recovery following lateral hypothalamic lesions. Life Sci., 1974, 15(12), 2079-2087.

[14] Grandas, F., Iranzo, A.: Nocturnal problems occurring in Parkinson's disease. Neurology, 2004, 63(8 Suppl. 3), S8-S11.

[15] Lees, A. J., Blackburn, N. A., Campbell, V. L., et al.: The nighttime problems of Parkinson's disease. Clin. Neuropharmacol., $1988,11(6), 512-519$.

[16] Happe, S., Schrödl, B., Faltl, M., et al.: Sleep disorders and depression in patients with Parkinson's disease. Acta Neurol. Scand., 2001, 104(5), 275-280.

[17] Lawrence, A. D., Evans, A. H., Lees, A. J., et al.: Compulsive use of dopamine replacement therapy in Parkinson's disease: reward systems gone awry? Lancet Neurol., 2003, 2(10), 595-604.

[18] Wong, J. C., Li, Y., Schwarzschild, M. A., et al.: Restless legs syndrome: an early clinical feature of Parkinson disease in men. Sleep, 2014, 37(2), 369-372.

[19] Eisensehr, I., Wetter, T. C., Linke, R., et al.: Normal IPT and IBZM SPECT in drug-naive and levodopa-treated idiopathic restless legs syndrome. Neurology, 2001, 57(7), 1307-1309.

[20] Allen, R. P., Barker, P. B., Webrl, F., et al.: MRI measurement of brain iron in patients with restless legs syndrome. Neurology, 2001, 56(2), 263-265.

[21] Arnulf, I.: Excessive daytime sleepiness in parkinsonism. Sleep Med. Rev., 2005, 9(3), 185-200.

[22] Chen, H., Schernhammer, E., Schwarzschild, M. A., et al.: A prospective study of night shift work, sleep duration, and risk of Parkinson's disease. Am. J. Epidemiol., 2006, 163(8), 726-730.

[23] Abbott, R. D., Ross, G. W., White, L. R., et al.: Excessive daytime sleepiness and subsequent development of Parkinson disease. Neurology, 2005, 65(9), 1442-1446.

[24] Paus, S., Brecht, H. M., Koster, J., et al.: Sleep attacks, daytime sleepiness, and dopamine agonists in Parkinson's disease. Mov. Disord., 2003, 18(6), 659-667.

[25] Hobson, D. E., Lang, A. E., Martin, W. R., et al.: Excessive daytime sleepiness and sudden-onset sleep in Parkinson disease: a survey by the Canadian Movement Disorders Group. JAMA, 2002, 287(4), 455-463.

[26] Jordan, A. S., McSharry, D. G., Malhotra, A.: Adult obstructive sleep apnoea. Lancet, 2014, 383(9918), 736-747.

[27] Da Silva-Júnior, F. P. Jr., do Prado, G. F., Barbosa, E. R., et al.: Sleep disordered breathing in Parkinson's disease: a critical appraisal. Sleep Med. Rev., 2014, 18(2), 173-178.

[28] Olanow, C. W.: The pathogenesis of cell death in Parkinson's disease. Mov. Disord., 2007, 22(Suppl. 17), S335-S342.

[29] Huang, J., Zhang, J., Lam, S. P., et al.: Amelioration of obstructive sleep apnea in REM sleep behavior disorder: implications for 
the neuromuscular control of OSA. Sleep, 2011, 34(7), 909915 .

[30] Floras, J. S.: Sleep apnea and cardiovascular risk. J Cardiol., 2014, 63(1), 3-8.

[31] Valko, P. O., Hauser, S., Werth, E., et al.: Heart rate variability in patients with idiopathic Parkinson's disease with and without obstructive sleep apnea syndrome. Parkinsonism Relat. Disord., $2012,18(5), 525-531$.

[32] Papp, M. I., Kahn, J. E., Lantos, P. L.: Glial cytoplasmic inclusions in the CNS of patients with multiple system atrophy (striatonigral degeneration, olivopontocerebellar atrophy and Shy-Drager syndrome). J. Neurol. Sci., 1989, 94(1-3), 79-100.

[33] Gagnon, J. F., Postuma, R. B., Mazza, S., et al.: Rapid-eye-movement sleep behaviour disorder and neurodegenerative diseases. Lancet Neurol., 2006, 5(5), 424-432.

[34] Fantini, M. L., Ferini-Strambi, L., Montplaisir, J.: Idiopathic REM sleep behavior disorder: toward a better nosologic definition. Neurology, 2005, 64(5),780-786.

[35] Miyamoto, T., Miyamoto, M., Inoue, ., et al.: Reduced cardiac 123I-MIBG scintigraphy in idiopathic REM sleep behavior disorder. Neurology, 2006, 67(12), 2236-2238.

[36] Boeve, B. F., Silber, M. H., Saper, C. B., et al.: Pathophysiology of REM sleep behaviour disorder and relevance to neurodegenerative disease. Brain, 2007, 130(11), 2770-2788.

[37] De Cock, V. C., Vidailhet, M., Leu, S., et al.: Restoration of normal motor control in Parkinson's disease during REM sleep. Brain, 2007, 130(2), 450-456.

[38] Lai, Ү. Y., Siegel, J. M.: Medullary regions mediating atonia. J. Neurosci., 1988, 8(12), 4790-4796.

[39] Merello, M., Hughes, A., Colosimo, C., et al.: Sleep benefit in Parkinson's disease. Mov. Disord., 1997, 12(4), 506-508.

[40] Gallagher, D. A., Goetz, C. G., Stebbins, G., et al.: Validation of the MDS-UPDRS part I for nonmotor symptoms in Parkinson's disease. Mov. Disord., 2012, 27(1), 79-83.

[41] Horváth, K., Aschermann, Zs., Ács, P., et al.: Validation of the Hungarian MDS-UPDRS: Why do we need a new Parkinson scale? [Az MDS-UPDRS magyar validációja: Miért szükséges újabb Parkinson-pontozóskála?] Ideggy. Szemle, 2014, 67(3-4), 129-134. [Hungarian]

[42] Horváth, K., Aschermann, Zs., Ács, P., et al.: Is the MDS-UPDRS a good screening tool for detecting sleep problems and daytime sleepiness in Parkinson's disease? Parkinsons Dis., 2014, 2014, 806169.

[43] Trenkwalder, C., Kohnen, R., Högl, B., et al.: Parkinson's disease sleep scale - validation of the revised version PDSS-2. Mov. Disord., 2011, 26(4), 644-652.
[44] Horváth, K., Aschermann, Zs., Ács, P., et al.: Test-retest validity of Parkinson's Disease Sleep Scale 2nd version (PDSS-2). J. Parkinsons Dis., 2014, 4(4), 687-691.

[45] Deli, G., Aschermann, Zs., Ács, P., et al.: Bilateral Subthalamic Stimulation can Improve Sleep Quality in Parkinson's Disease. J. Parkinsons Dis., 2015 Mar 10. [Epub ahead of print]

[46] Miletin, M. S., Hanly, P. J.: Measurement properties of the Epworth sleepiness scale. Sleep Med., 2003, 4(3), 195-199.

[47] Morgenthaler, T., Kramer, M., Alessi, C., et al.: Practice parameters for the psychological and behavioral treatment of insomnia: an update. An American Academy of Sleep Medicine report. Sleep, 2006, 29(11), 1415-1419.

[48] Menza, M., Dobkin, R. D., Marin, H., et al.: Treatment of insomnia in Parkinson's disease: a controlled trial of eszopiclone and placebo. Mov. Disord., 2010, 25(11), 1708-1714.

[49] Medeiros, C. A., Carvalhedo de Bruin, P. F., Lopes, L. A., et al.: Effect of exogenous melatonin on sleep and motor dysfunction in Parkinson's disease. A randomized, double blind, placebocontrolled study. J. Neurol., 2007, 254(4), 459-464.

[50] Frucht, S., Rogers, J. D., Greene, P. E., et al.: Falling asleep at the wheel: motor vehicle mishaps in persons taking pramipexole and ropinirole. Neurology, 1999, 52(9), 1908-1910.

[51] Lou, J. S., Dimitrova, D. M., Park, B. S., et al.: Using modafinil to treat fatigue in Parkinson disease: a double-blind, placebo-controlled pilot study. Clin. Neuropharmacol., 2009, 32(6), 305310 .

[52] Mendonca, D. A., Menezes, K., Jog, M. S.: Methylphenidate improves fatigue scores in Parkinson disease: a randomized controlled trial. Mov. Disord., 2007, 22(14), 2070-2076.

[53] Aurora, R. N., Kristo, D. A., Bista, S. R., et al.: The treatment of restless legs syndrome and periodic limb movement disorder in adults - an update for 2012: practice parameters with an evidence-based systematic review and meta-analyses: an American Academy of Sleep Medicine Clinical Practice Guideline. Sleep, 2012, 35(8), 1039-1062.

[54] Takeuchi, N., Uchimura, N., Hashizume, Y., et al.: Melatonin therapy for REM sleep behavior disorder. Psychiatry Clin. Neurosci., 2001, 55(3), 267-269.

(Faludi Béla dr., Pécs, Rét u. 2., 7623 e-mail: bela.faludi@gmail.com) 